\title{
Taiwan's Intra-Asian Trade and Migration in the 1930s
}

\author{
Man-houng Lin \\ Institute of Modern History, Academia Sinica, Taipei, Taiwan, ROC
}

\section{Email address:}

mhlmh@gate.sinica.edu.tw

\section{To cite this article:}

Man-houng Lin. Taiwan's Intra-Asian Trade and Migration in the 1930s. History Research. Vol. 8, No. 1, 2020, pp. 19-32. doi: $10.11648 /$ j.history.20200801.13

Received: January 18, 2019; Accepted: February 17, 2020; Published: February 18, 2020

\begin{abstract}
Since the start of the 21st Century, trading relations among the East Asian countries have been and need to be strongly reinforced. By reviewing intra-Asian economic relations in the 1930s, we could see assets and load left by history to the present world. In the 1930s, Taiwan was ruled by Japan. By contrast with Hori Kazuo, a professor of Kyoto University to have touched upon the intra-Asian trade of this decade focusing upon Japan, this study depicts the intra-Asian trade and migration of this decade by focusing upon Taiwan. This paper obtains the following findings: 1. In the 1930s, Taiwan's trade with the Northeast Asia had been vividly increased. The increase rate of trade between Taiwan and Manchukuo as well as Korea was greater than that between Taiwan and the Japan proper. Migration between Taiwan and all Asian areas in this period was in general increased, in which that to China increased most. All these increases had been made possible by the rise of Asia-Pacific navigation relative to the Asia-European navigation. 2. In this expansion of intra-Asian trade and migration, the national boundary with all these various areas for Taiwan was clearly observed rather than imagined. For example, following the treaty between Japan and Korea signed in 1910, the relation between Taiwan and Korea turned more and more from being international into being domestic. When Taiwanese products, deemed as Japanese products, were rejected in the Southeast Asia and welcome in Manchukuo and other newly Japanese conquered Chinese mainland, Taiwanese vested interest was more and more intertwined with the Japanese empire which climaxed its war victory in China by conquering Wuchang and Hankou in 1938. By contrast with the mostly labor population among immigrants from other Asian areas to Taiwan, many of the emigrants from Taiwan to these areas were rich merchants.
\end{abstract}

Keywords: Merits and Demerits of Colonization, Japanese Empire and China, Relations Among Colonies, Asia-Pacific, Peace and War in the 1930s

\section{Introduction}

From the start of the $21^{\text {st }}$ Century, the trading relations among the East Asian countries have undergone profound change. According to the data of Japan External Trade Organization (JETRO), since 2001, the value of Japan's imports from the top nine East Asian countries, headed by the PRC, Korea and the ROC (Taiwan), has exceeded the total of those from the US and Europe. The same applies for exports since 2002. Countries in East Asia also in general have other East Asian countries as well as the US as their main trade partners. [1] By reviewing intra-Asian economic relation in the 1930s, we could see some positive and negative legacies left by history to the present world.

Throughout the 1930s Taiwan was under the rule of Japan. Hori Kazuo showed in his study on the general history of
Japan's intra-Asian trade in the 1930s that, under the influence of the US-originated Great Depression, Japan shifted its focus from tight economic links with the US to expand instead the country's co-operative relations in Asia. In the course of this expansion, the Japanese invasion of China, partly the result of the demand for economic resources and market, also transformed relations between different regions of China and Japan. [2]

While Hori Kazuo has focused on Japan, my research and that of Xu Shirong, a Ph.D. of Taiwan Normal University, working under my supervision and now a professor of National Taichung Educational University, has centered on Taiwan, discussing its role in intra-Asian trade during the Japanese colonial period between 1895 and 1945. [3] Xu has studied trade between Taiwan and the Chinese mainland, finding that the 1930s saw a clear decline of trade between both sides; the primary causes of this were mainland boycotts 
in response to the Japanese invasion, which included products from Japanese-ruled Taiwan. Between 1940 and 1945, with Japan's expansion of the East Asian war, the coastal regions of China came under the control of the Japanese-backed government, trade between Taiwan and these areas increased. My own research on Taiwan's foreign trade expands to include Taiwan's trade with Southeast Asia, Hong Kong, Manchuria, and Japan proper. Study of Hong Kong has shown that the sharp rise of Pacific trade in the 1930s greatly influenced changing relations among Taiwan, Japan and Europe. Building on my own existing work, I also address the largely merchant-based Taiwanese emigration. Taiwanese traders, with their Chinese cultural background, often acted as middlemen between the Chinese world and Japan when Japanese intra-Asian trade expanded. The Japanese invasion of China, however, also caused these traders to face identity dilemma.

This paper extends to include Taiwanese trade with and emigration to Korea, relying on the Archives of Taiwan General-Government and contemporary survey records with the invitation of the Iwanami Shōten. [4] Additionally, using materials including previously collected trade statistics, publications by the Bank of Taiwan and Taiwan General-Government and distributed among various countries, newspapers and biographies, and materials on Asian history from the National Archives of Japan and the Kōbe Newspaper Clippings Collection, I have added a treatment of Taiwanese trade with Southeast Asia to the previous study on Taiwanese investment in Southeast Asia, and further added to my previous work on Taiwanese migrants across Asia with discussion of Japanese, Korean, and Chinese migrants in Taiwan as well as the establishment of these areas' respective Consulates. From my previous focus on individual relations between Taiwan, Manchukuo, and Southeast Asia, this paper looks more comprehensively at Taiwan's intra-Asian trade and migration links.

\section{The Rise of Pacific Trade}

In the 1910s, judging by the volume of shipping, Hong Kong was the largest port in East Asia. By the 1930s, however, it had fallen into seventh place in the world, behind Kōbe in third place and Ōsaka in fifth, with New York, London and Rotterdam respectively occupying first, second and fourth place. The Korean and Taiwanese ports of Pusan, Dalian, Jilong and Gaoxiong, engaged in trade with Japan, likewise saw a sharp rise.

Hong Kong's dominance from its founding in 1842 until the 1910s was largely due to the importance of the Atlantic route between Europe and Asia at a time of growing relations between East Asia and Europe and America. Most of Taiwan's Oolong tea bound for New York in late nineteenth century and early twentieth century was shipped via Xiamen, Hong Kong, Southeast Asia, the Indian Ocean, and the Atlantic, rather than the Pacific. In 1869 work finished on the Suez Canal, and the new route through the Red Sea proved difficult to navigate with sailing ships. British particular involvement with the Canal opening thereby spurred the development of steamer transport, and Hong Kong, serving as the East Asian coal supply point for British steamers, grew in importance.

British power in East Asian trade, however, began to decline after the Russo-Japanese war. Moreover, 1914 saw the opening of the Panama Canal, largely through US efforts, and with the outbreak of war in Europe the US was able to develop trade in the Pacific, with the result that by the 1930s Kōbe and Ōsaka had surpassed Hong Kong. Taiwanese Oolong tea bound for the US was largely now shipped via the Pacific. [5]

This rise of Pacific trade in the 1930s served as a basis for the intra-Asian movement of Taiwanese goods and people.

With regard to goods, in this period Taiwanese trade with Japan, Manchuria, and Korea expanded, while there was a relative decline in its trade with China and Southeast Asia, and on occasions with Hong Kong and India.

\section{Expansion of Trade with Northeast Asia}

Korea had seen little trade with Taiwan prior to the Japanese annexation of this kingdom in 1910. From 1910 on Koreans exported ginseng and soy beans and imported salt, canned pineapples, and sugar via Hong Kong, China or Japan. Direct exports of sugar and salt from Taiwan to Korea gradually began. Direct exports of Korean ginseng to Taiwan began in 1914. [6] This trade was conducted in Pusan and Incheon in Korea, and in Gaoxiong, Anping, and Jilong on Taiwan. Until 1927, however, trade relations between Korea and Taiwan remained weak, with little direct trade; two or three products made up the bulk of trade each year. [7]

From 1910 trade statistics for Korean-Taiwanese trade gradually shifted from referring to 'exports and imports' (between countries) to internal trade. Between 1904 and 1909 a table showing 'Value of Imports and Exports For Trade With Taiwanese Ports' accompanied trade statistics between Korea and China, Hong Kong, British-ruled India, the French-ruled Indo-China Peninsula, the Dutch Indies, Russia-ruled Asia, the Philippines, and Thailand. [8] For the years 1910 and 1911 the compilers used a separate table showing 'Value of Trade Between the Ports of Korea and Taiwan'. [9] Even between 1910 and 1920, however, Article Three of the 1910 Declaration of Annexation governed fishing and customs relations between Korea and Taiwan, treating Taiwan as a foreign country. [10] For the ten years following 1910, relations between Japan, Korea, and other colonies continued on an international basis. Thus goods shipped from Korea to Japan and Sakhalin levied importation duties for foreign countries and an equal value of import tax for domestic other areas. Ships from Korea docking at Japanese ports likewise were taxed according to tonnage in the same way as other foreign ships, and similar charges applied to Taiwanese exports to Korea. The regulations restricted shipping between Japan, Taiwan, Sakhalin, and 
Korea to designated ports, again under the same principles that governed foreign shipping. [11] This system maintained the pre-1910 status quo: Article One of the shipping law stated that Korean ships were not recognized as Japanese, while according to Article Three they could not dock at undesignated ports on Japan and Sakhalin or transport goods and people between these ports. [12]

In 1918 international taxes were levied on Korean products exported to Taiwan. [13] This was followed in 1920 by the end of these taxes on products shipped to Korea from Japan, Taiwan, and Sakhalin. [14] In 1920 boats passing between Taiwan and Korea, like those between Japan and its other colonies, were treated as Japanese boats. [15]

Following the suspension of the shipping route between Gaoxiong and Dalian operated by the Ōsaka Commercial Steamship Company in 1928, new routes opened in April of that year between Taiwan, Korea, and Manchuria, with ships carrying fruits, molasses and other specialties from Taiwan to Korea and Dalian; these were direct routes between the colonies. [16] Although the volumes carried by this direct trade between Taiwan and Korea remained small, they steadily increased. In Korea the most important ports for export were Pusan, Gyeongseong (now Seoul), Incheon, and Wonsan, while activity on Taiwan centered on Gaoxiong, Jilong, and Anping. [17] Taiwan's principal exports were rice, bananas, pineapples, sugar, salt and coal; Korea mainly exported ginseng and salted fish. In each month of the year 1936 there were three return journeys made between the two colonies by two-to-four thousand ton ships, with the journey lasting ten days. In contrast to the shipping lines between Taiwan and Japan, shipping lines between Taiwan and Manchuria or Korea were operated by government order. (See Table 1, Figure 1)

Table 1. Shipping lines between Taiwan and Korea (1936).

\begin{tabular}{lllllll}
\hline $\begin{array}{l}\text { Shipping } \\
\text { line }\end{array}$ & $\begin{array}{l}\text { By order or } \\
\text { independent }\end{array}$ & Frequency & $\begin{array}{l}\text { Time to } \\
\text { destination }\end{array}$ & Carried & $\begin{array}{l}\text { The names of the } \\
\text { dispatched ships }\end{array}$ & Shipping route \\
\hline $\begin{array}{l}\text { Gaoxiong } \\
\text { to Chongjin }\end{array}$ & By order & $\begin{array}{l}\text { Once each } \\
\text { month }\end{array}$ & Ten days & $\begin{array}{l}\text { Passengers } \\
\text { and goods }\end{array}$ & $\begin{array}{l}\text { Ōsaka Commercial } \\
\text { Steamship Company } \\
\text { Kana ship 2, 567 tons }\end{array}$ & $\begin{array}{l}\text { From Gaoxiong: Gaoxiong, Jilong, Kagoshima, } \\
\text { Nagasaki, Hakata, Pusan, Chongjin. } \\
\text { To Gaoxiong: same as above with additional } \\
\text { stops including Unggi, Songjin, and Xingnan. }\end{array}$ \\
$\begin{array}{l}\text { Gaoxiong } \\
\text { to Incheon }\end{array}$ & By order & $\begin{array}{l}\text { Twice each } \\
\text { month }\end{array}$ & $\begin{array}{l}\text { Five days to } \\
\text { Dalian } \\
\text { Ten days to } \\
\text { Incheon }\end{array}$ & $\begin{array}{l}\text { Passengers } \\
\text { and goods }\end{array}$ & $\begin{array}{l}\text { Nippon Yusen } \\
\text { Iwate ship 4, 000 tons } \\
\text { Gifu ship 4, 000 tons } \\
\text { Genmei ship 4, 000 tons }\end{array}$ & $\begin{array}{l}\text { From Gaoxiong: Gaoxiong, (Jilong), Dalian, } \\
\text { month stopped at Jilong) } \\
\text { To Gaoxiong: same as above, stopping at Jilong } \\
\text { twice a month. }\end{array}$ \\
\hline
\end{tabular}

Source: Takaoshu, Takaoshu Sangyo chosakai Shogyo boekibu shiryo (Materials from the Gaoxiong Industrial Survey Committee: Commerce and Trade Section ( Takao-shu: Commerce and Trade Section, 1936), p. 443.

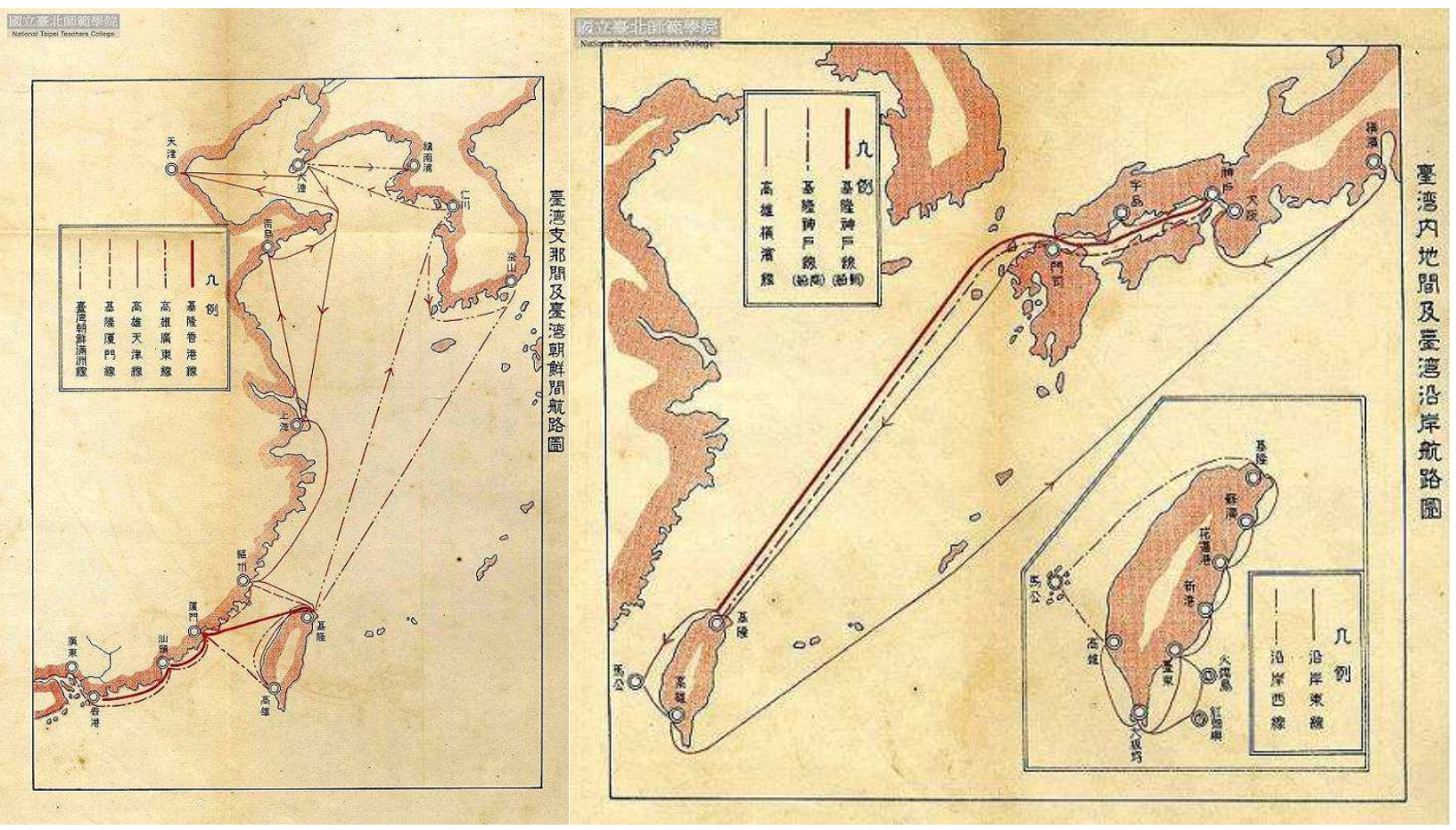

Figure 1. Shipping routes between Taiwan, Manchuria, and Korea.

Source: Taiwan Sōtokufu Kōtsūkyoku Teishinbu Communications Section of the Transportation Bureau, Taiwan General-Government), Taiwan no kaiun (Taiwan's shipping) (Taipei: Taiwan Sōtokufu Kōtsūkyoku Teishinbu, 1930), following p. 17. 
Faster shipping routes served to transport perishable goods such as bananas. (Table 2)

Table 2. Major shipping routes for bananas (1936).

\begin{tabular}{lll}
\hline Shipping route & The Navigation Times in the Banana Season & Time required \\
\hline Gaoxiong-Tokyo Line & 9 & 6 days \\
Gaoxiong-Osaka Line & 9 & 6 days \\
Gaoxiong-Dalian-Tianjin Line & 9 & 7 days \\
Taiwan-Manchuria-KoreanLine & 2 & 6 days \\
Gaoxiong-Fuzhou-Shanghai Line & 3 & 7 days \\
Jilong-Kobe Line & 11 & 4 days \\
\hline
\end{tabular}

Source: Takaoshu, Takaoshu Sangyo chosakai Shogyo boekibu shiryo, p. 150.

Among Japanese-ruled areas trading with Taiwan between 1931 and 1935, Korea occupied the sixth-highest place by trade volume (Table 3).

Table 3. Taiwan's trade with regions of Japan and Korea (1931-1935).

\begin{tabular}{|c|c|c|c|}
\hline Region & Yearly trade value (thousand Japanese yen) Average over five years & Percentage & Rank \\
\hline Hokkaidō & 7,982 & 2.2 & 7 \\
\hline Keihin (Tōkyō, Kawasaki, Yokohama) & 100,815 & 27.2 & 2 \\
\hline Nagoya & 21,683 & 5.9 & 4 \\
\hline Hanshin (Ōsaka and Kobe) & 148,546 & 40.1 & 1 \\
\hline Hiroshima & 4,182 & 1.1 & 8 \\
\hline Kanmon & 34,172 & 9.2 & 3 \\
\hline Kyūshū and Okinawa & 20,312 & 5.5 & 5 \\
\hline Other areas & 24,477 & 6.6 & \\
\hline Total & 370,230 & 100 & \\
\hline
\end{tabular}

Source: Takaoshu, Takaoshu Sangyo chosakai Shogyo boekibu shiryo, p. 481

Korea, like all areas of Japan other than Ōsaka and Kobe, experienced a trade deficit (Table 4).

Table 4. Trade balance between Taiwan and Japan proper (1931-1935).

\begin{tabular}{|c|c|c|c|}
\hline Area & $\begin{array}{l}\text { Yearly internal export (thousand } \\
\text { Japanese yen) Average over five years }\end{array}$ & $\begin{array}{l}\text { Yearly internal import (thousand } \\
\text { Japanese yen) Average over five years }\end{array}$ & $\begin{array}{l}\text { Trade surplus } \\
\text { (surplus/export, percentage) }\end{array}$ \\
\hline Hokkaidō & 5,014 & 2,968 & $2,046(40.8)$ \\
\hline Keihin (Tōkyō, Kawasaki, Yokohama) & 84,996 & 15,819 & $69,177(81.4)$ \\
\hline Nagoya & 17,241 & 4,442 & $12,799(74.2)$ \\
\hline Hanshin (Ōsaka and Kobe) & 66,993 & 81,553 & ------------------ \\
\hline Hiroshima & 2,094 & 2,088 & $16(0.3)$ \\
\hline Kanmon & 18,967 & 15,205 & $3,762(19.8)$ \\
\hline Korea & 5,287 & 2,774 & $2,513(47.5)$ \\
\hline Others & 13,920 & 10,557 & $3,363(24.2)$ \\
\hline Total & 230,580 & 139,650 & $90,930(39.4)$ \\
\hline
\end{tabular}

Unit: thousand Japanese yen

Source: Takaoshu, Takaoshu Sangyo Chosakai shogyo boekibu shiryo, p. 481.

As Table 5 shows, between 1933 and 1939 the value of exports from Taiwan to Korea more than quadrupled, an increase around double that of exports to other Japanese-ruled areas. At the same time, imports from Korea increased by around five times, showing a rate of increase between two and three times that of imports from other areas (see Table 6). This import-export ratio thus rose to surpass that of trade with Okinawa and Hokkaido (see Tables 5 and 6). Moreover, in the 1930s the two-to-threefold increase in trade with Japanese proper did not match the huge expansion of total trade with Manchukuo or of imports from there. Following the establishment of Manchukuo in 1932, Taiwanese trade with the region saw a sharp increase from 15, 835, 000 yen in 1932 to $45,519,000$ in 1938. Imports from Manchukuo to Taiwan increased with particular rapidity, rising almost tenfold from 1, 999, 000 in 1932 to 19, 325, 000. Exports from Taiwan to Manchuria almost doubled in the same period, from 13, 836, 000 to $26,194,000$. This can be attributed largely to the Manchukuo's Five Year Plan, which called for a great variety of materials. Additionally, there was little commonality between the bean products and modern fertilizers produced in dry, cold Manchuria and the fruits and vegetables grown in Taiwan's warmer and wetter climate. Though in the course of this trade Taiwan generally experienced an import surplus, the fertilizer products which took up much of these imports aided agricultural development. [18]

The increase in trade after the establishment of Manchukuo is particularly clear if we view it as a percentage 
of Taiwan's trade with areas other than Japan proper. Between 1906 and 1931 trade with Manchukuo averaged only $2.76 \%$ of Taiwan's total foreign trade (foreign trade does not include the trade with Japan proper in the Japanese colonial period); between 1932 and 1939 it averaged 48.35\%. [19] Of course, for Manchuria, trade with Taiwan was far less important than with Japan. Between January and October 1933 the volume of trade between Manchuria and Taiwan accounted for only $1.1 \%$ of Manchuria's total. [20] In 1939, the year for which we have figures, products from Taiwan took up only $4.4 \%$ of the total value of Dalian's imports, compared to $72.8 \%$ for Japan, $7.1 \%$ for China, $5.3 \%$ for the US. It was, however, higher than Europe's 3.4\% and Korea's 3\%. [21]

Rice, sugar, and tea could be shipped to Japan proper without being charged the export duty imposed when these products were shipped elsewhere, because from 1911 the two areas had both been incorporated within the same customs system, and these commodities turned into Taiwan's major exports there. [22] Between 1930 and 1939 Japan proper accounted for $92.18 \%$ and $82.57 \%$ of Taiwan's total exports and imports respectively. [23] Prior to the Marco Polo Bridge incident of 1937, the ratio of Taiwan's internal import and export to Taiwan's foreign imports and exports saw little change, with the former remaining on average at $87.7 \%$ and the latter at $12.3 \%$. Much of the internal export and import was occupied by Japan proper. Following the outbreak of war, internal import and export saw a relative increase to $90.3 \%$ in 1937 and $90.9 \%$ in 1938; foreign export and import declined to $9.7 \%$ and $9.1 \%$. As exports from Taiwan to Japanese-ruled or influenced areas of China rose sharply in 1939 , the proportion of trade with Japan proper fell to $86.63 \%$.
[24] Imports and export trade with states other than Japan in 1937 occupied only one tenth of the total trade, and came to only one-ninth of the value of trade with Japan proper. Although in 1939 there was some increase in this trade with other countries, it still accounted for only a seventh of Taiwan's total trade or a sixth of internal export and import trade with Japan proper. Where goods produced in Taiwan and were needed in Japan as much as possible would have been shipped there; likewise, Japan was the source for as much as possible of the items needed by the Taiwanese. Imports from other countries to Taiwan were largely items which Japan could not supply, or supplied in insufficient quantities. [25]

The major products for internal export to Japan from Taiwan were rice, sugar, fruit, and hats; the most important internal export market was Kantō, followed by Kansai, Kyūshū, Korea, Hokkaido, and Okinawa. Kansai supplied an overwhelming proportion of Taiwan's internal import, with the most common items being cotton goods and grocery goods from Ōsaka. By the 1930s, however, the significance of Kansai declined while Kantō, Korea, and Kyūshū saw increases. [26] The period between 1923 and 1935 saw Taiwan's economy flourishing, with industrial production and gross national income per capita both more than doubling that prior to the First World War. In this period, at least prior to the outbreak of the Pacific War, Taiwan's income from trade and other relations with Japan proper exceeded its expenses. The majority of this export surplus was used to expand production. [27] Rice exports and fertilizer, textiles, and iron imports in the 1930s saw a significant rise from the 1920s; imports of cigarettes, alcohol, and opium, on the other hand, decreased.

Table 5. Taiwanese exports to Japan proper and Korea.

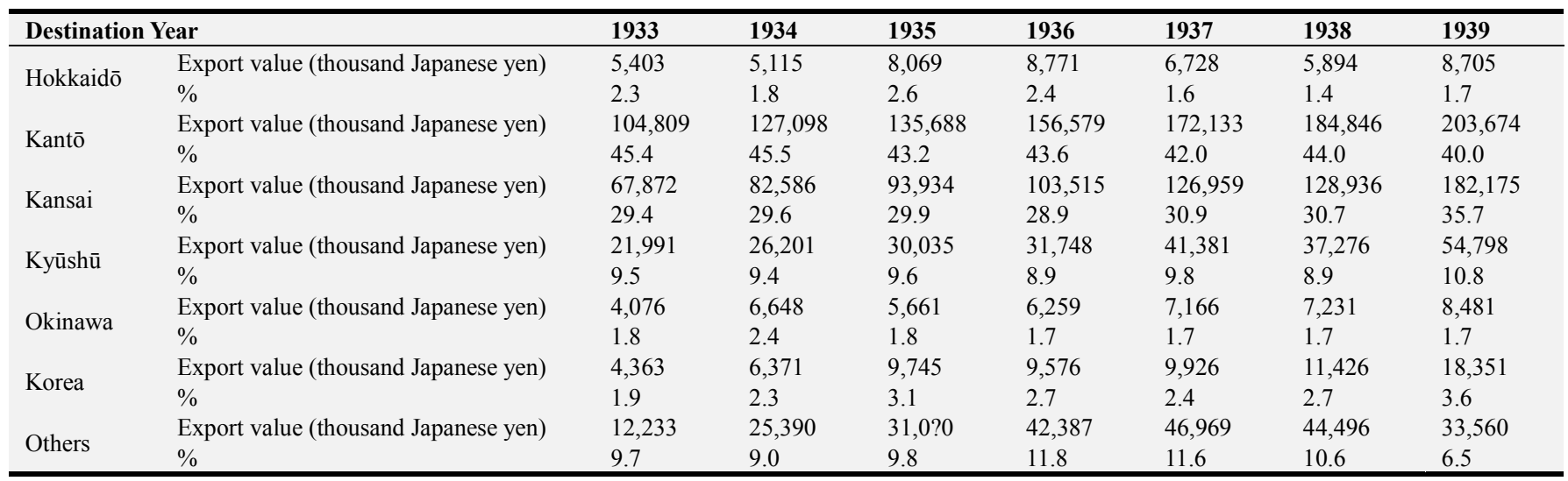

Source: Taiwan keizai nenpō kankōkai (ed.), Taiwan keizai nenpō (Taiwan’s annual economic report) (Tōkyō: Kokusi Nihon Kyōkai, 1941 ), p. 604.

Table 6. Taiwanese imports from Japan and Korea.

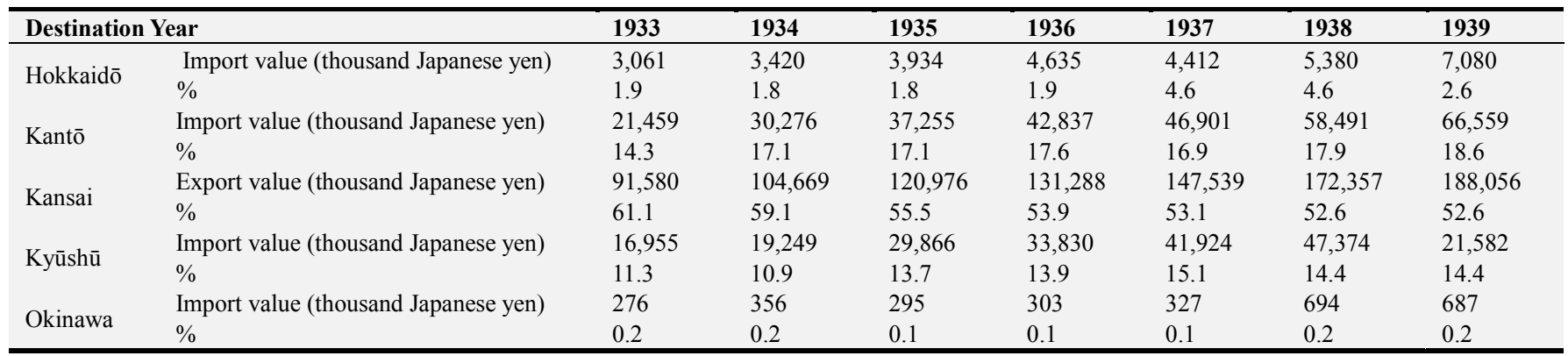




\begin{tabular}{|c|c|c|c|c|c|c|c|c|}
\hline \multicolumn{2}{|c|}{ Destination Year } & 1933 & 1934 & 1935 & 1936 & 1937 & 1938 & 1939 \\
\hline \multirow{2}{*}{ Korea } & Import value (thousand Japanese yen) & 3,832 & 5,265 & 7,198 & 8,788 & 11,890 & 15,328 & 16,873 \\
\hline & $\%$ & 2.6 & 3.0 & 3.3 & 3.6 & 4.3 & 4.7 & 4.7 \\
\hline \multirow{2}{*}{ Others } & Import value (thousand Japanese yen) & 12,748 & 13,755 & 8,618 & 22,151 & 24,861 & 28,325 & 26,770 \\
\hline & $\%$ & 8.5 & 7.8 & 8.5 & 9.0 & 8.9 & 8.6 & 7.5 \\
\hline
\end{tabular}

Source: Taiwan keizai nenpō kankōkai, Taiwan keizai nenpō (Tōkyō: Kokusi Nihon Kyōkai, 1941), p. 604-605.

It is clear from Figure 2 that Taiwan's trade with Manchuria was more developed in the 1930s than its trade with northern and southern China and Southeast Asia. At first the trade with southern China was greater, but it fell far behind after Manchukuo's establishment. Between 1932 and 1939 Taiwan's trade with Manchukuo on average accounted for
$67.6 \%$ of its trade with the different regions of China, while southern China occupied only $11 \%$. Even after the establishment of Manchukuo, Taiwan's trade with central China remained higher than its trade with the north, though this and the still lower volume of trade with Southeast Asia remained far below trade with Manchukuo.

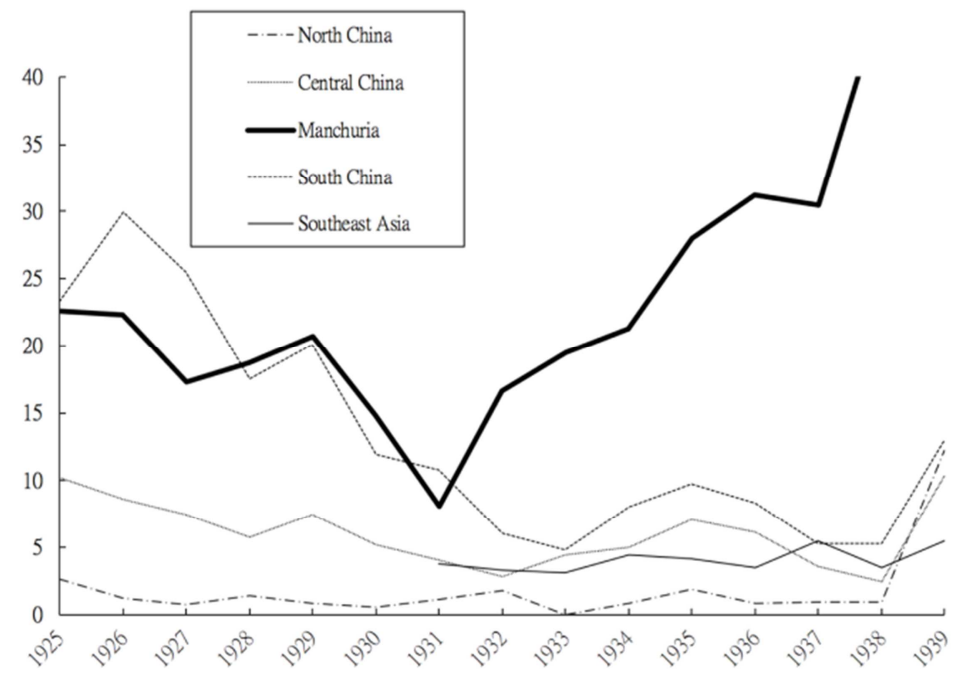

Figure 2. Trade between Taiwan and various areas in China and Southeast Asia.

Source:

1. Figures for 1925-1939 from Taiwan Sōtokufu Sōtoku Kanbō Chōsaka, Shina no jikyoku to shina bōeki no shōchō (The current situation of China and the growth and decline of Chinese trade), Minamishina oyobi nan'yō chōsa (Investigation about the Southern China and the South Seas Area), Taipei: the editor, 1928 , no. 143 , p. 170.

2. Figures for 1927-1936 from Taiwan Sōtokufu Kanbō Gaijika, Taiwan to Minami Shina: bōeki (Taiwan and south China: Trade), Minamishina oyobi nan'yō chōsa, Taipei: 1927 , no. 236, p. 43.

3. Figures for 1935-1939 from Taiwan Sōtokufu Zaimukyoku, Taiwan tai nanshi nan'yō bōekihyō (Tables for Taiwanese trade with south China and Southeast Asia (Shōwa 14), with yearly figures for Manchukuo, Guandong leased territory, and north and central China added, p. 1.

Unit: million Japanese yen

Note: data for 1925 and 1926 include Xiamen, Fuzhou, Shantou, Guangzhou, Quanzhou, Haikou, and Beihai in south China.

In contrast with the increase of Taiwanese trade with northeast Asia, trade with China and with Southeast Asia declined in the 1930s due to anti-Japanese movements. This varied across different regions and countries, however. In the early 1930s Taiwan's exports to Hong Kong, Thailand, Indonesia, and the Philippines declined, before rising again for a number of years. Although imports from Taiwan's major good suppliers India and Indonesia were higher overall in the 1920s than in the 1930s, some years in the latter decade saw increases (see Figures 3, 4, and 5). While under Japanese rule Taiwan's predominant export to Southeast Asia was baozhong tea, with other goods including coal, cardboard, cement, and sulphur. At the beginning of the early twentieth century Javan sugar was a major import; with the increase of Taiwanese sugar production, however, this saw a reduction. Other imports included white spirits from the Malaysian peninsula, rice and coal from Vietnam, rice and timber from
Thailand, and leaf tobacco and timber from the Philippines. [28]

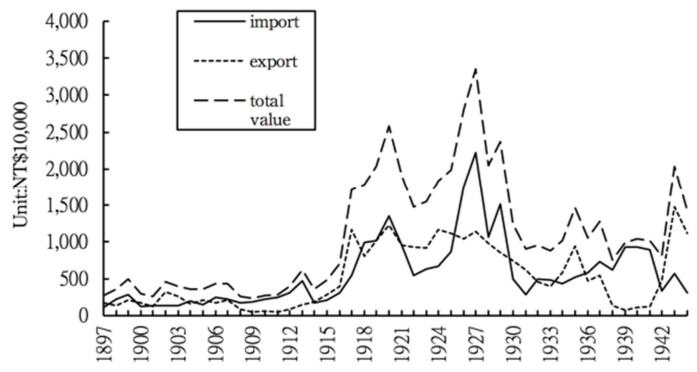

Figure 3. Trade value between Taiwan and Southeast Asia (1896-1944).

Source: Taiwan sheng xingzheng zhangguan gongshu tongishi, Taiwan sheng 51 nian lai tongji tiyao (Summary of statistics for Taiwan over the last 51 years) (Taipei: Taiwan sheng xingzheng zhangguan gongshu tongjishi, 1946), pp. 962-963, 966-967. 


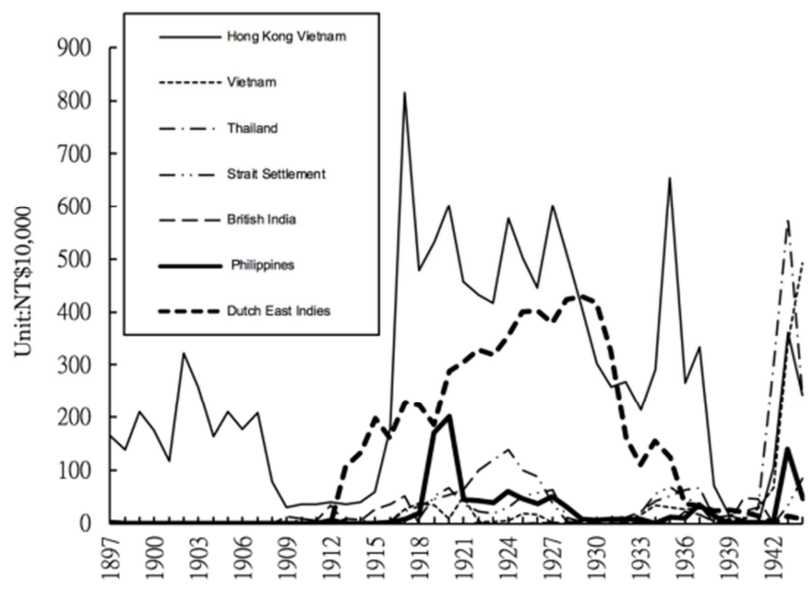

Figure 4. Taiwan's export value to various Southeast Asian countries (1897-1944).

Source: Taiwan sheng xingzheng zhangguan gongshu tongjishi, Taiwan sheng 51 nian lai tongji tiyao (Summary of statistics for Taiwan over the last 51 years) (Taipei: Taiwan sheng xingzheng zhangguan gongshu tongjishi, 1946), pp. 966-967.

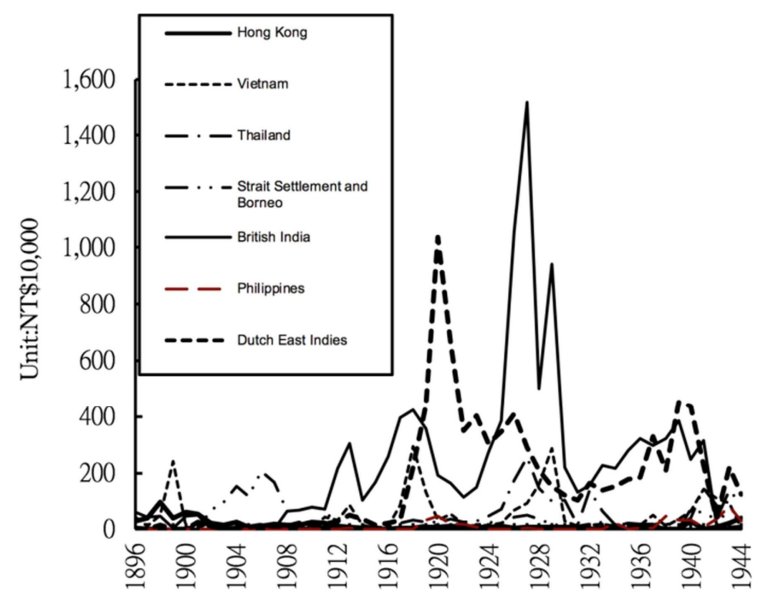

Figure 5. Taiwan's import value from various Southeast Asian countries (1896-1944).

Source: Taiwan sheng xingzheng zhangguan gongshu tongjishi, Taiwan sheng 51 nian lai tongji tiyao, pp. 962-963.

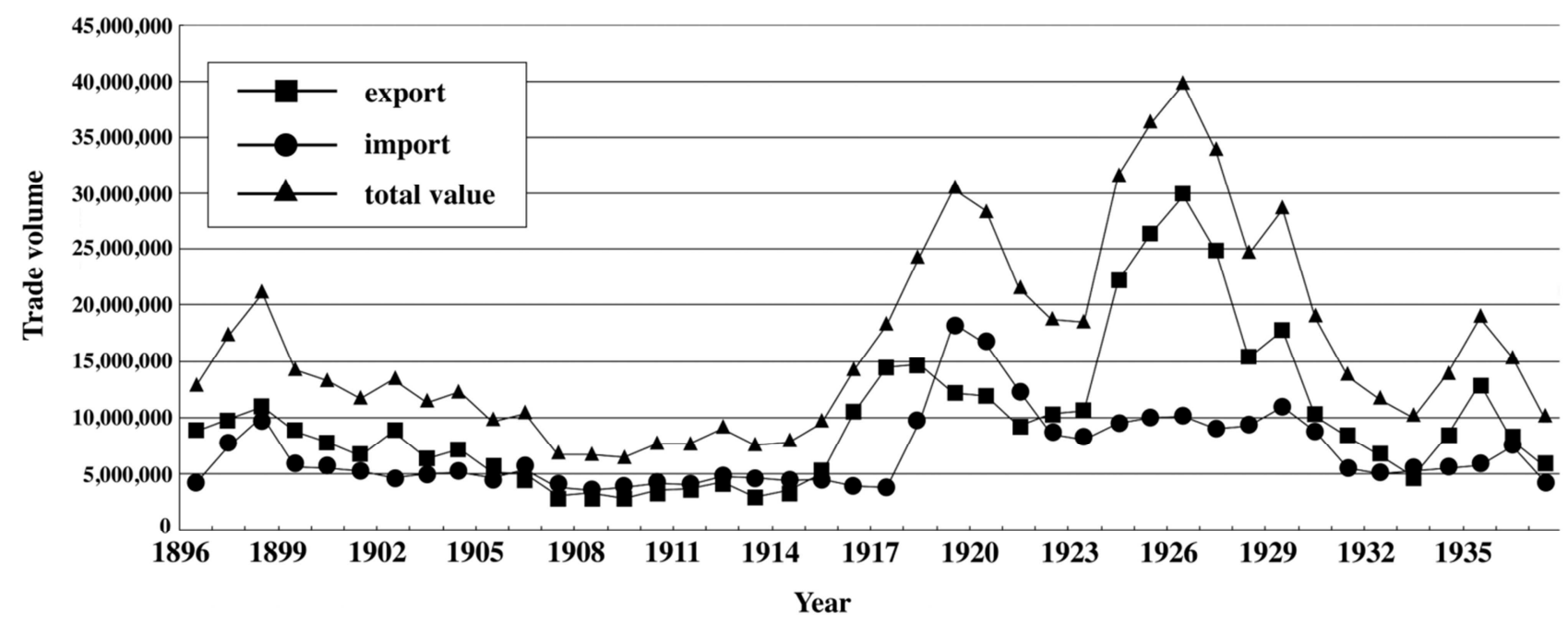

Figure 6. Trade Value between Taiwan and China (1896-1937).

Source: 1896-1935 data from Taiwan bōeki yonjūnen hyō (Tables on the Taiwanese economy over forty years), p. 9, 394, 407-408; Taiwan no bōeki (Taiwan's trade), pp. 35- 38, 41- 42; 1936-1937 data from Taiwan tai nanshi nan'yō bōekihyō (Tables on Taiwanese trade with south China and Southeast Asia) (Shōwa 14), p. 1. Graph from Xu Shirong, 'Guanshui yu liang'an maoyi, 1895-1945,' p. 14.

In its trade with China, Taiwan generally exported more than it imported ( See Figure 6), while the reverse was true for trade with Southeast Asia (see Figure 3). Prior to 1931 the volume of Taiwanese trade with China was around half that of its trade with all other countries, sometimes exceeding half; in this period, other than 1910 when China was very slightly behind the US, China consistently accounted for the most trade, making China second only to Japan in trade volume. Manchukuo's establishment in 1932 had an evident impact, lowering Taiwan's trade with China. In the two or three years before 1937 the largest Taiwan's exports to China were fruits, dried fish, salted fish, dried shellfish, and matches, with lamp oil, vegetable oil, coal, and cement also accounting for a significant amount; there was also a small export of iron. Japanese products were also exported to China via Taiwan.
Wheat bran, garni bag, burlap, and medicines were imported in large quantities from China [30]

Although in the 1930s Taiwan's trade with Korea and Manchuria clearly expanded, as did its trade with Japan proper, there was a relative decline in trade with China and Southeast Asia, causing Taiwan's trade to shift all the more toward the Northeast Asia. With regard to population movements, however, general increases can be observed between Taiwan and Northeast and Southeast Asia and China, particularly southern China.

\section{Intra-Asian Migration and Taiwan}

After 1937, the number of Japanese immigrants on Taiwan rose from at most five percent of the total population to nearly 
ten percent. The initially low level of migration can be explained by the lack of population pressure within Japan proper. From 1926 on population pressure in Japan proper gradually rose, and the Japanese authorities responded by carrying out military-backed emigration to northeast China. Until the outbreak of the Pacific War Japanese migration to Taiwan remained at the minimum level necessary for the operation of a colony. With the war underway, an active policy of southward expansion resulted in increased migration to Taiwan, especially of people connected to the military. In the previous forty-five years, most of the Japanese immigrants from Japan proper were colonial administrators, industrial advisors and those involved in commerce. Those involved in primary industries accounted for only a very small proportion, with only senior employees and a small number of technical experts working in the mining industry; agricultural workers were also present only in small numbers, initially in Yoshino village near the port of Hualian.

Chinese migration to Taiwan also increased in the 1930s. Figures 7 and 8 show Chinese migration to Japanese-occupied Taiwan from the Chinese mainland. By the 1940s the total number of immigrants was 45, 661, seventy-eight percent of whom were labors. Many of the rest were also poor: while overseas Chinese people in Southeast Asia had capital ranging from millions to tens of millions and hundreds of millions of Japanese yen, the richest on Taiwan at most had three hundred thousand, with amounts over fifty thousand being rare. Changes in immigration from China are clear from Figure 7, with an increase in number of people throughout the period of Japanese rule from thousands in the 1900s to forty or fifty thousand in the 1930s and 1940s. As Figure 8 demonstrates, some chose to stay long term on Taiwan while others worked there only temporarily. Between 1900 and 1920 the most common temporary workers were in the tea trade, with rickshaw pullers second; in the 1930s and 1940s miscellaneous labors were in the majority.

This labor-dominated migration differentiated the period of Japanese rule from the Qing dynasty. In 1902 the Japanese Ministry of Foreign Affairs noted that the jiao (Taiwanese trade association) merchants in institutions like the Quanjiao Huiguan at Lugang had in the past monopolized this port's trade across the Taiwan Straits; by 1902 their power had declined, but eight stores (Jincheng, Kuncheng, Yuanfa, Faxiang, Fumei, Hengcheng, Yuancheng and Futonglong) took on the majority of the trade and maintained it, with merchants in their collective trade association having forty to fifty boats. Very few of these merchants were locals. Their boats travelled between Quanzhou, Zhangzhou, and Taiwan, transporting products as part of the trade between Xiamen, Shenhu, Quanzhou, Xinghua, Fuzhou, and Tongzhou along the Chinese coast and Danshui, Jiugang, Donggang, Bengang, Lugang, Anping, Gaoxiong, and Penghu Magong on Taiwan. [29] Thus mainland immigrants to Taiwan in the Qing dynasty included powerful investors. [30]

With the still-increasing numbers of migrants in the 1930s, a Republic of China consulate was established in Taipei on April first, 1931; this closed on February first, 1938. Initially set up in rented offices at the Lin Ben Yuan company premises in Dadaocheng, this consulate moved in 1934 to the Zhang mansion (now 112-114 Zhongshan North Road Section 2) (Figure 9). After 1945, this building had served as the Embassy of Japan in the Republic of China for a while before its being knocked down, with the Yuanshan branch of Huanan Bank occupying its location at present. [31]

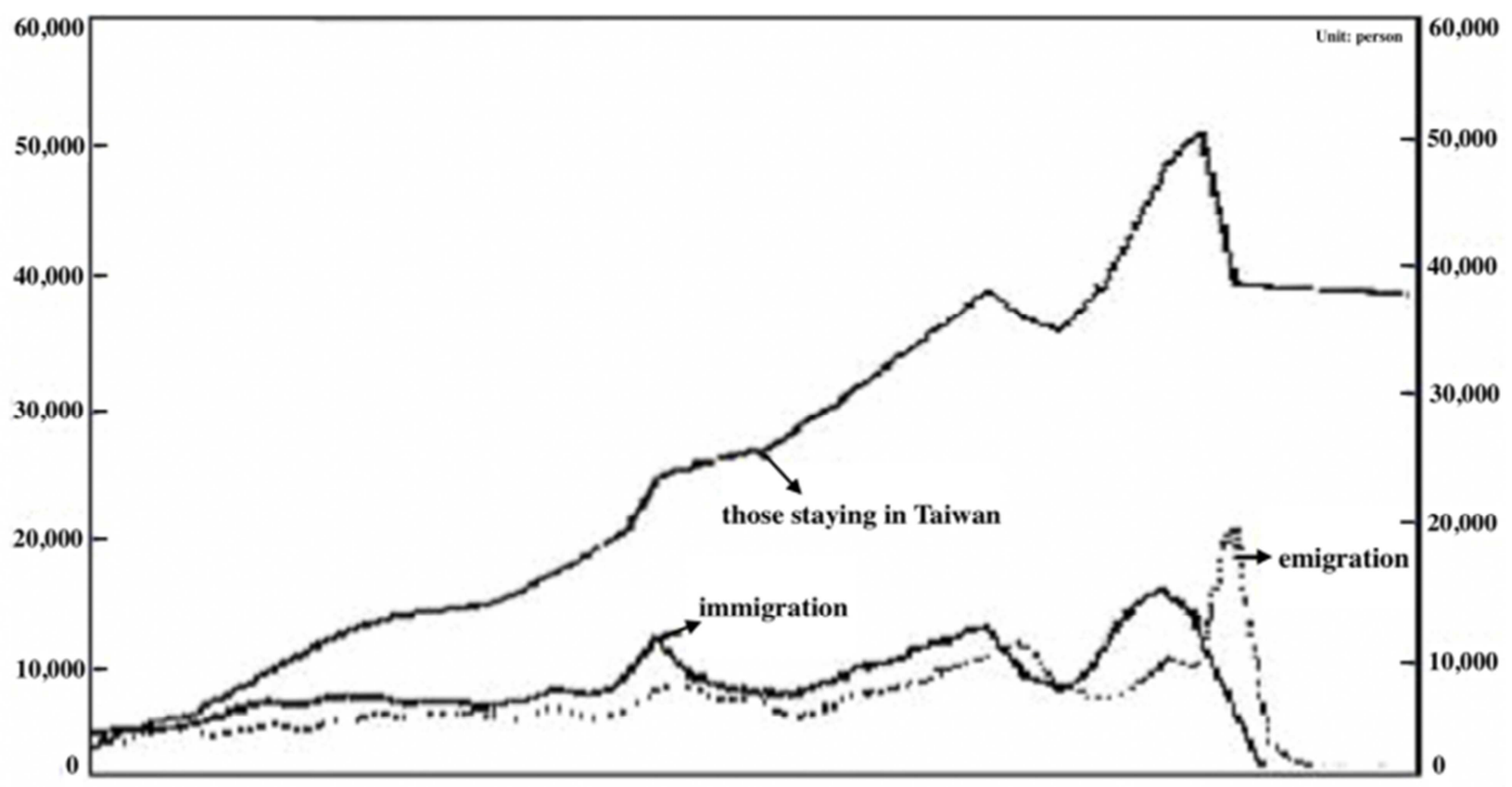

19061907196819091910191119121913191419151916191719181919192019211922192319241925192619271928192919301931193219331934193519361937193819391940194119421943 (Vear)

Source: Shibuya Naga'nori, Matsuo Hiroshi, Taiwan no kakyō (Overseas Chinese on Taiwan), Taiwan keizai nenpō, chapter 6, Shōwa 18 (1943), p. 421.

Figure 7. Chinese Migration across the Taiwan Strait. 


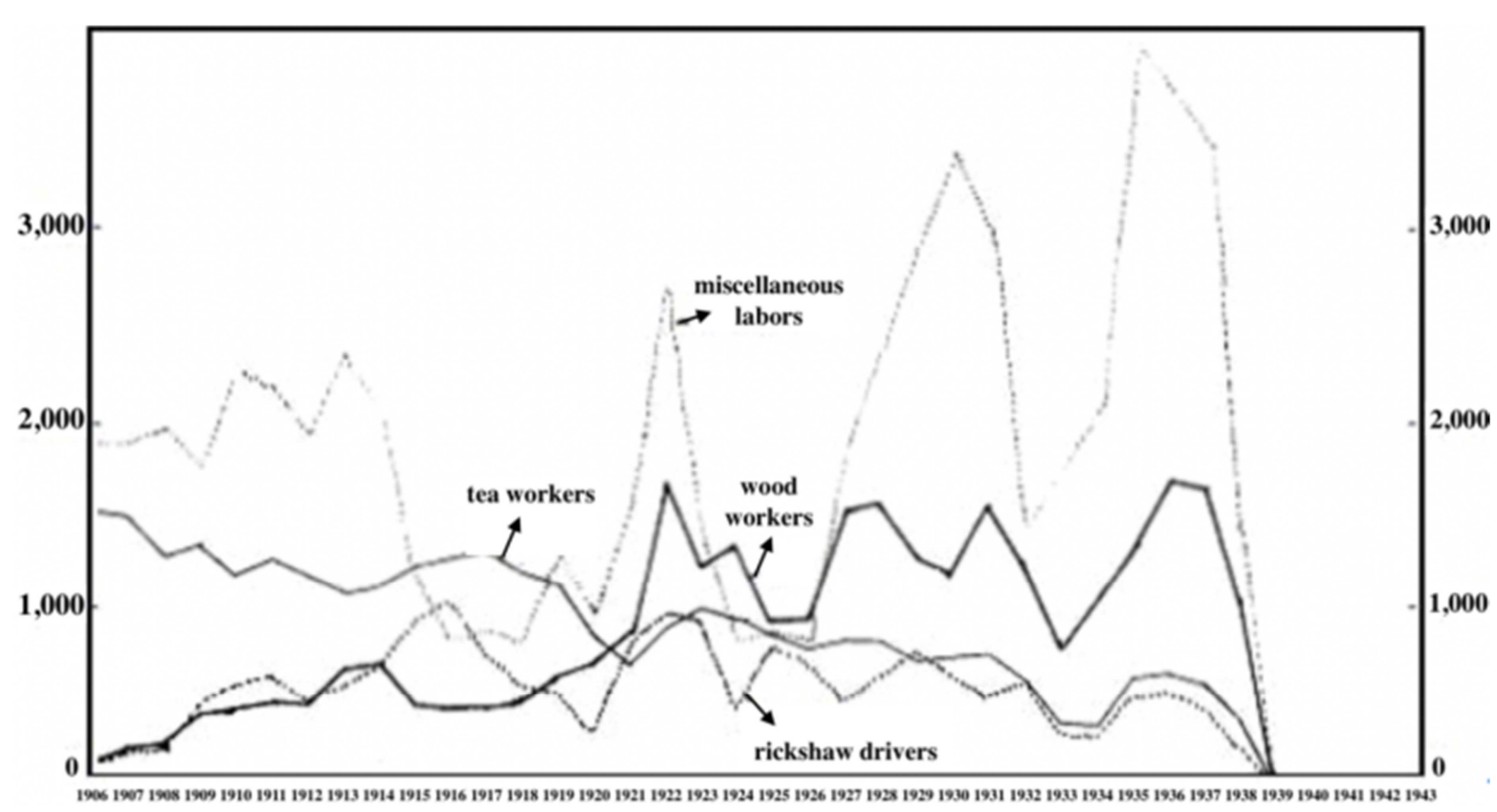

Source: Shibuya Naga'nori, Matsuo Hiroshi, Taiwan no kakyō (Overseas Chinese on Taiwan), Taiwan keizai nenpō, chapter 6, Shōwa 18 (1943), p. 420.

Figure 8. Chinese Migration according to type of labor.

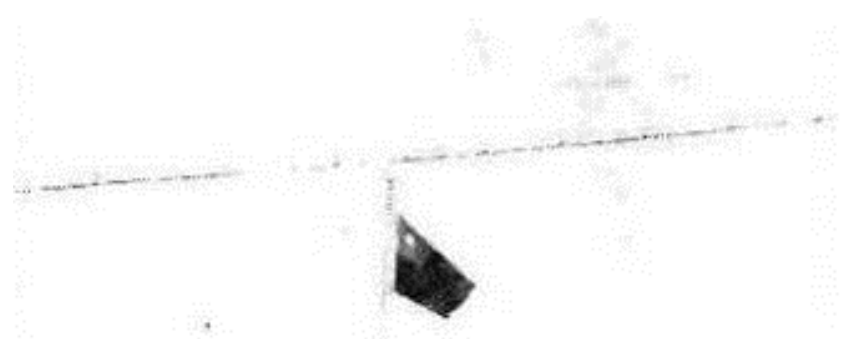

397,060 , or $6 \%$, those from the Republic of China 52,020 $(0.8 \%)$, and Koreans 2,775 (0.04\%). [32] Koreans were thus the most important immigrant group after the Japanese from Japan proper and people from the Republic of China. In the 1930s the number of Koreans on Taiwan increased from less than a thousand to two thousand; throughout this time Korean women outnumbered men (Table 7).

Table 7. Korean population on Taiwan (1932-1943).

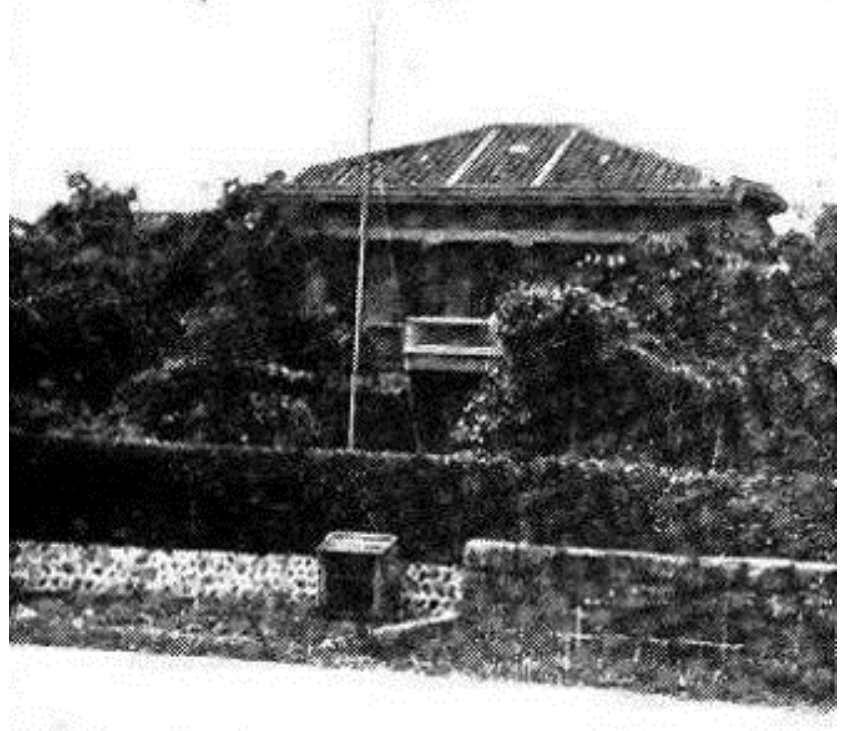

Source: Taiwan nichinichi shinpō, April 1, Shōwa 6

Figure 9. Republic of China Consulate in Taipei (1931-1938).

In 1943 the total population of Taiwan stood at $6,585,841$. Of this figure, the native population of $6,133,867$ accounted for $93.1 \%$, Japanese inhabitants from Japan proper numbered

\begin{tabular}{llll}
\hline Year & Total & Male & Female \\
\hline 1932 & 959 & 323 & 636 \\
1933 & 1,191 & 417 & 774 \\
1934 & 1,316 & 470 & 846 \\
1935 & 1,604 & 583 & 1,021 \\
1936 & 1,694 & 568 & 1,126 \\
1937 & 1,985 & 772 & 1,213 \\
1938 & 1,903 & 763 & 1,140 \\
1939 & 2,260 & 880 & 1,380 \\
1940 & 2,299 & 794 & 1,505 \\
1941 & 2,539 & 921 & 1,618 \\
1942 & 2,692 & 1,013 & 1,679 \\
1943 & 2,775 & 1,066 & 1,709 \\
\hline
\end{tabular}

Source: Taiwan Sotokufu, Taiwan jōjū kokō tōkei: Shōwa 18 (Taiwan household registration: Shōwa 18) (Taipei: Taiwan Sotokufu, 1944), p. 108.

Prior to 1928 Korean immigrants were most commonly employed in the aquatic products industry and trade, with public servant or freelancer and household workers also taking up a significant proportion; employment in agriculture was very rare. [33] Between 1936 and 1941 the importance of trade rose relative to the aquatic products industry, but by 1902 public servant or freelancer had replaced the former. Employment in trade and the aquatic products industry showed a clear decline, with the latter in particular reduced to 
almost zero. In 1941, 279 Koreans arrived in Taiwan from the Republic of China, Vietnam, the Philippines and other places, of whom 153 were male and 126 female. [34]

In 1944 there were ninety-three residents of Taiwan with citizenship from other countries; of these four were Taiwanese people who had obtained foreign citizenship and one was a Japanese person with foreign citizenship. Clearly, residents from places other than Japan, the Republic of China and Korea were extremely rare. Although in 1934 there had been a plan to set up a Manchukuo embassy in Taipei, [35] by 1945 this embassy had still not been established. [36]

In contrast to the development of trade, in the $1930 \mathrm{~s}$ Taiwanese migration expanded to northeast Asia, the Republic of China (especially the south of China), and to Southeast Asia; moreover, in the 1930s migrants to China remained the most numerous.

Migrants from Japanese-ruled Taiwan to southern China totaled 335 in 1907; by 1936 this had risen to 12,900 . [37] This represents the number registered; adding the unregistered migrants gives a total of 30,000. Around twenty or twenty-one thousands of these moved to Fujian, with Xiamen accounting for eighteen thousand, Fuzhou for two thousand, and several hundred going to Zhangzhou and Quanzhou. [38] Most of the Taiwanese people in Shanghai arrived there from Fujian and Guangdong, with somewhere between six and eight hundred there between 1935 and 1937. There was a slight decline with the outbreak of war in 1937, but the number increased again after Japan took control of Shanghai in 1938. [39] In 1911 there were around sixty Taiwanese people in northeast China, which had risen to five hundred by the 1932 establishment of Manchukuo, and again to six hundred by 1938. [40] By the end of the war in 1945 there were around one thousand Taiwanese people in Manchukuo. [41] By 1926 around 522 Taiwanese people had moved to Southeast Asia, [42] and by 1942 this had risen to around three thousand. [43] In Japan there were 1,703 Taiwanese people in 1920, 4,611 in 1930, and 22,499 by 1940 . [44] Whether workers or students, the number of Taiwanese people in Japan did not match that of Koreans.

By contrast with the Chinese and Korean immigrants, many of whom were from the lower levels of society, those migrating from Taiwan often went to open shops, factories, and farms. Statistics from the Fujian provincial government in 1937 show that in Xiamen, the place with the highest number of Taiwanese immigrants, $81.18 \%$ were merchants and $4.51 \%$ doctors. Other than the $7.85 \%$ who were prostitutes, percentages for other trades were all low. In Fuzhou $68.18 \%$ were merchants, $8.36 \%$ doctors, $7.48 \%$ government workers, and 5.28\% teachers. [45] In Southeast Asia, most migrants to British-ruled Borneo were farmers, while a large number of those who went to Singapore and Malaysia worked in tin mines or rubber plantations; migrants to other places were largely merchants. In 1935 the Taiwan Development Company was established, with the Taiwanese merchants Gu Xianrong, Lin Xiongzheng, Chen Qifeng, and Yan Guonian invited to become shareholders. Around fifty-five Taiwanese people worked in the Southeast Asia branch of the company as planners and engineers, among other positions. With the support of the Company and Taiwan General-Government, Taiwanese people also engaged in agriculture in Borneo. The founding of the Tropical Industry Research Committee in 1935 strengthened economic links to Southeast Asia, with funding from Taiwanese people including Lin Xiongzheng, Gu Xianrong, and Liu Mingchao. 1935 also saw a shift from the previous Japanese policy, which since 1915 had only seen Japanese people trained to go to Southeast Asia, with the inclusion of Taiwanese people; the Taihoku College of Commerce in Taipei and Chia-Yi Commercial School in Tainan carried out this training. In 1936, the Taiwan Chamber of Commerce set up with its membership endorsed by the government, and a liason for Taiwan's merchants, consented to assist Taiwan to serve as a station for Japan's expansion to Southeast Asia in the wartime system. In 1937 Taiwan General-Government supplied Taiwanese residents in Thailand with a subsidy of two-to-three thousand yen, forming the most organized Taiwanese trade association in Southeast Asia and using this to strengthen the role of Taiwanese merchants there in selling products for Japanese merchants. [46]

\section{Conclusion}

The most obvious feature of Taiwanese intra-Asian commerce in the 1930s was the expansion of trade with the Northeast Asia; the growth of trade with Japan itself confirms Hori Kazuo's view that in the 1930s Japan strengthened trading ties with its colonies, but this research has also highlighted the fact that the expansion of Taiwan's trade with Manchukuo and Korea was still greater than that with Japan. Additionally, we have seen that while migration from Korea and Japan to Taiwan, and from Taiwan to Japan and Manchukuo, increased, the numbers moving did not match those migrating to China. Chinese migration to Taiwan also saw an increase, while the movement of Taiwanese people to Southeast Asia received more of the Japanese state support. The rise of Asia-Pacific shipping, in comparison to Euro-Asian shipping, provided an important basis for this movement of goods and people.

In contrast to Hori Kazuo's focus on the relations between the colonizing country and each colony, this paper has discussed the relations between colonies and on the integration of the colonizing country and the colonies. This integration can be seen in the case of Korea: on the 1910 Japanese takeover, customs and the use of harbors were arranged on an international basis, before policy shifted between 1918 and 1920 to treat Korea as part of Japan. Trade statistics from 1931 to 1935 and 1933 and 1939 moreover included Korea in the list of Japanese cities with which Taiwan traded (see Tables 3, 4, and 5). While the building in Figure 9 may resemble present Taipei with its Republican flag, in fact it was the Consulate of the Republic of China. In terms of trade, migration, and consular matters, the dividing line between countries was very clear; it was not a production of political authorities' imaginations as cultural historian 
Prasenjit Duara now at Duke University suggest. [47]

A Republic of China Consulate remained in Taiwan from the Japanese 1931 annexation of Manchuria until 1938, while migration between Taiwan and China, and between Taiwan and Southeast Asia, continued to increase; evidently the annexation did not bring about an immediate hostility between China and Japan. Taiwanese business leader Gu Xianrong, who in 1895 welcomed Japanese troops to Taipei and had received a medal from Japan's House of Peers, went to China in 1934 and 1935 to meet Chiang Kai-shek, Wang Jingwei and others on a common anti-Communist basis, seeking to ensure the exchange of diplomatic envoys and for Japan to recall rōnin in Fujian. Gu again returned to China in February and March 1937, in poor health and just a few months from his death (at the age of seventy-two, in December of the same year). As Chiang Kai-shek was ill, Gu conveyed to Chiang Japan's statement that it wished to maintain the Great Wall as a dividing line and promote peace in East Asia via Minister of Foreign Affairs Zhang Qun, Businessman Du Yuesheng, and Finance Minister and Acting Premier Kong Xiangxi. Japanese infiltration of China, including its aiding of smuggling in the northern China, made reconciliation difficult, however. [48]

Following the invasion of Manchuria, relations between Taiwan and the Chinese mainland increasingly tended toward opposition and even hostility. The loss of Manchuria reduced Chinese exports by a third; as Wang Yeh-chian has argued, this was a major reason for economic crises in China in the 1930s. [49] On the Taiwanese side, however, while there was some reduction of trade with China and Southeast Asia, trade with Japan, Korea, and Manchuria markedly increased. While agricultural products, fish, and minerals remained the mainstay of this commerce, exports to Japan sometimes included industrial products like cement, cardboard, lamp-oil, vegetable oil, and alcohol. In this period Taiwan moreover generally benefited from a trade surplus; even when there was a trade deficit, many of the items imported were materials for production.

The 1971 Taiwan Province Gazetteer claimed that 'under Japanese rule, Japanese zaibatsu and government monopolized Taiwan's foreign trade, and Taiwan's people lacked experience in selling abroad', suggesting discrimination toward the people of Taiwan from the Japanese colonial authorities. [50] In practice, those Japanese living on Taiwan could indeed receive different treatment to migrants from Japan. But outside Taiwan, both received the same treatment. Japanese officials received an additional subsidy of fifty to sixty percent of their salary; thus, though their basic salary might be lower than those working in Japan, they earned much more than Taiwan residents. Lin Yongcang, who worked for the Taiwan Power Company, recalled that 'there was a huge difference in the treatment of graduates from the Taipei School of Industry depending on whether they were Japanese or Taiwanese... when we went out to do measure work, I would not only have to carry the equipment but also have to instruct them in how to do the measurement, while Japanese workers... would get nearly sixty percent more travel subsidy than me; the discrimination was unbearable'. For this reason, he decided to continue his studies in Manchuria. Due to various subsidies, the income of those abroad was often significantly higher than those on Taiwan. Huang Yongde, a graduate from the department of electricity, who in 1941 went to work for the Fuda company (part of the Taiwan Development Company) in Xiamen, and receive the Gulanshu Power Company recounts that in addition to basic salaries, workers there received war-zone and danger subsidies, as well as overtime pay and travel expenses. Both Japanese and Taiwanese workers travelling abroad received the same subsidies; this motivated not a few Taiwanese people to travel to Manchukuo, central and southern China, Hainan, and Southeast Asian destinations like Vietnam. [51]

Aside from receiving the same level of additional subsidies as Japanese workers, Taiwanese people travelling abroad also benefited from a status equal to that of European expatriates. In 1910 Someya Shigeaki, the first Japanese Consul in Jakarta, successfully achieved that Taiwanese residents be accorded the same legal rights as Japanese citizens. Taiwan, like India, had been colonized; in the Dutch East Indies, however, Indians from both British and French colonial territories received the same level of treatment as Malaysians, while both Japanese and Taiwanese people benefited from equal status with Europeans. This is clear in the case of two brothers, the younger a Chinese and the older a Taiwanese citizen, both with 300, 000 yuan; tax on the former was twice of that paid by the latter paid. [52] Securing this equal status for Taiwanese expatriates served as a means of facilitating Japan's expansion in East Asia, because Taiwan and China shared a common cultural background and because the cooperation of Taiwanese workers and capital could contribute to Japan's investments in southern China and Southeast Asia, which were restricted to its existing investment in Manchukuo and northern China. [53] For the same reason, during the 1930s when, with the exception of Japanese colonial government workers, most migrants were from the lower levels of society, migrants from Taiwan, especially those bound for China and Southeast Asia, tended to be wealthy merchants.

Though some Taiwanese migrants had extended business beyond Asia, most carried out intra-Asian trade. $\mathrm{Xu}$ Wang, for example, who in 1906 had arrived in Kōbe, opened a Paris shop in 1921 for trading various goods between Japan and Britain, Italy, Russia, Spain, Portugal and other countries, then in 1932 went to Dalian to trade in marine products and fruits, and in 1934 returned to Kōbe to export fruits, maritime products, and various foodstuffs to Southeast Asia. [54] By the 1930s the wealthy Banqiao Lin family achieved predominance in currency exchanges between Taiwan, Hong Kong, and Xiamen. There was also Taiwanese success in the tea trade: in the 1890s mainland Chinese merchants had dominated the transport of Taiwanese baozhong tea to the Dutch East Indies and other destinations, and by the 1910s overseas Chinese in the Dutch East Indies came to the fore, but by the 1930s the Taiwanese Chen Tianlai's company in Dadaocheng was pre-eminent. 
In the wake of the invasion of Manchuria anti-Japanese sentiment in China reached a peak. With the outbreak of full-scale war on July 7,1937, some Taiwanese people went to China to take part in the war against Japan [55]; others however found themselves in the opposite camp. Taiwanese people were active in the Japanese-controlled regions of China; as noted above, some welcomed the war as a 'holy war' due to the opportunities it provided for financial gain. Figure 10 shows a photograph of a celebration in Zuozhen, a southern Taiwan township, of the Japanese capture of Hankou in October 1938. Following the takeover Zhuang Sichuan, born in Chia-yi in Taiwan, a graduate of the Chinese Literature department of Shanghai University, worked as head of the Dachu and Wuhan newspapers in Wuhan and printed propaganda for the Japanese army. [56]

In the decade between the Mukden Incident of 1931 and the fall of Wuhan, while markets for Taiwanese trade contracted in China and Southeast Asia, they expanded on Japan and particularly in the newly-formed Manchukuo and Korea, while increasing numbers of Japanese, Chinese, and Korean migrants arrived on Taiwan. At the same time greater numbers of Taiwanese citizens moved to China and Southeast Asia to expand their economic opportunities, and in so doing received Japanese state support. In this process of greater integration between Taiwan and Japan, the Japanese authorities increasingly brought the people of Taiwan into the war with China. An archeology of knowledge, probing this history long neglected, and obscured by complex attitudes toward the war could shed light on the often conflicting attitudes toward China and Japan of longstanding Taiwanese inhabitants and those who came to the island from the Chinese mainland after 1945, and those who remained on the Chinese mainland.

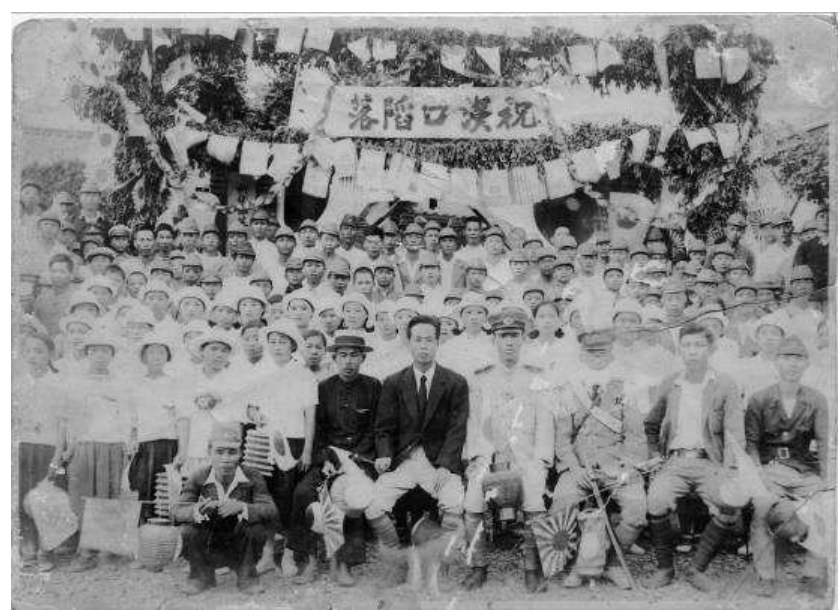

Figure 10. Tainan's celebration for the fall of Hankou in October, 1938.

Source: Yeh Chunjung, Zuozhen lishi tuxiang (Historical images of Zuozhen township) ( Tainan: Tainan district government, 2003 ) book cover, with the courtesy of Mr. Yeh Chunjung.

In comparison with Anne Booth of School of Oriental and African Studies in London University and Kent Deng of London School of Economics and who stress on the different degree of Asian colonies 'development and different colonizer's policies in the early twentieth-century, [57] this paper depicts more on the positive and negative sides in the trade and migration relations among China, Japan, Korea, the Southeast Asian countries, and Taiwan. While this paper compares some of the migrant pattern of Korea and Taiwan between these two areas and the Taiwanese migration pattern to the whole Asian region, Kent and Anne paint more on the Korean migration to the whole Asian area.

\section{References}

[1] http://www.jetro.go.jp/jpn/stats/data/pdf/trade2005.pdf.

[2] Hori Kazuo, 'Sen kan ki higashi Ajia ni okeru kōgyō teki bungyō. seisan zai bōeki no bunseki o tsūjite' (Division of labor in East Asian industry in the interwar period: an analysis of production and trade), in Nakamura Satoru ed., Higashi Ajia kindai keizai no keizei to hatten- Higashiajia shihon shugi keizeishi (The formation and development of East Asian modern economy: a history of the formation of the East Asian capitalism) 1 (Tōkyō: Nihon Hyōronsha, 2005), Section 5, pp. 117-143; Hori Kazuo, Ryō taizenkanki Nihon teikoku no keizaiteki hen'yō: sekai shijō niokeru ichi (Transformation of the Japanese empire's economy in the interwar period: position in world markets), in Nakamura Satoru ed., Kindai higashi Ajia keizai no shiteki kōzō- Higashi Ajia shihon shugi keizieshi (The historical structure of modern East Asian economy: a history of the formation of the East Asian capitalism) 3 (Tōkyō: Nihon Hyōronsha, 2007), Section 4, pp. 153-180.

[3] Xu Shirong, 'Guanshui yu liang'an maoyi, 1895-1945' (Customs duties and trade across the Taiwan Straits, 18951945) (Taipei: National Taiwan Normal University, doctoral thesis, 2005), pp. 16-18.

[4] Lin Man Houng, "Sen kyuhyaku sanju nendai Taiwan no Ajia chiikinai ni okeru bōeki to imin (Taiwan's intra-Asian trade and migration in the 1930s), Iwanami kōza higashi Ajia kingendai tsüshi (Iwanami lectures on modern and contemporary East Asian history) (10 vols. Separate volume 1) Vol. 5: Shinchitsujo no mosaku: 1930-nendai (Searching for a new order: the 1930s) (Iwanami Shoten, 2011), pp. 151-172. This author thanks Dr. David William Bowles' preliminary translation helps for this papers.

[5] Man-houng Lin, "Taiwan, Hong Kong, and the Pacific, 1895-1945," Modern Asian Studies, vol. 44, no. 5 (September, 2009), pp. 1053-1080.

[6] 'Xian shen zhishu yingxiang (The effects of the direct ginseng trade), 'Taiwan nichinichi shinpō, July 25, Taishō 3.

[7] Taiwan Sōtokufu zaimukyoku (Bureau of Finance, Taiwan General-Government), Taishō 7 Taiwan bōeki gairan (Overview of Taiwan's Economy, 1918) (Taipei: Taiwan Sōtokufu zaimukyoku zeimuka, 1921), p. 267.

[8] Taiwan Sōtoku Kanbō Bunshoka, Taiwan Sotokufu Dai hachi tôkei sho (Meiji 37) (Eighth statistics collection of the Taiwan General-Government) (Taipei: Taiwan Sotokufu, 1906), pp. 503, 564-565, 675 .

[9] Taiwan Sōtokufu zaimukyoku (Bureau of Finance, Taiwan General-Government), Meiji 44 Taiwan bōeki gairan (Outline of Taiwan's trade, 1911) (Taipei: Taiwan Sōtokufu zaimukyoku, 1914), p. 258. 
[10] Taiwan Sōtokufu gōbun ruisan (Documents of the Taiwan General-Government), vol. 46-5307-4-8, Finance section 4, Imports and exports), October Meiji 43, p. 21, September 10, Meiji 43: Head of Customs Sekurai Tetsutarō 1) Goods transported to Korea are to be managed as export goods; 2) Fishing boats travelling between Taiwan and Korea are to be dealt with as before; 3) according to article three of the Declaration of the Annexation of Korea, treaty countries may not carry out coastal trade between Korean and Japanese ports. On p. 24, September 13, Meiji 43 Acting Head of Customs Fuse Kentarō: items traded from this island to Korea fall under the rules for exports, and need to pay export duty, following number eighty-two of the regulations of Meiji 23.

[11] 'Hontō oyobi Chōsen kankei (The relation between this island and Korea),' Taiwan nichinichi shinpō, September 7, Meiji 43 (September 7, 1910)

[12] Taiwan Sōtokufu gōbun ruisan, vol. 49-1815-13- 8, Finance, part 4, Imports and exports, Meiji 44. p. 206, Korea.

[13] Taiwan Sōtokufu gōbun ruisan, vol. 53- 6559- 9-8, Finance, part 4, Imports and exports, no. 3826, Taishō 7, p. 39, Chōsen seisan buppin no inyūzei menjo ni kansuru ken (The document on the exempt of internal import taxes for imported goods from Korea), no. 1469.

[14] Taiwan sotokufu gobun ruisan, vol. 64 (volume 63062, document 11, section 8, Finance, part 1, Imports and exports, no. 5873), p. 268, November Taishō 9 'Taiwan yori Chōsen ni ishutsu suru buppin no ni kannai kokuzei suru ken', Government Order no. 311 (August 25, Taishō 9 according to Law 51, Taishō 9 stated that goods transported from Japan, Taiwan and Sakalin to Korea were not to be charged internal taxes).

[15] Taiwan sotokufu gobun ruisan, vol. 64 (volume 63062, document 11, section 8, Finance, part 1, Imports and exports, no. 5873), pp. 326, 333: according to government order no. 168 on preventing shipping between Taiwan, Japan, Sakhalin, and Korea, the previous law no. 312, of August in Meiji 43, treating shipping between Korea and Taiwan as foreign trade, was annulled on September 28, Taishō 9.

[16] Ariya Shōichi, Taiwan kaiunshi (History of Taiwanese maritime trade) (Gaoxiong: Kabushiki kaisha kaiun bōeki shinbun Taiwan shisha, 1942), p. 153.

[17] Taiwan Sōtokufu zaimukyoku, Taishō gannen itari go nen Taiwan bōeki gairan (Survey of Taiwanese trade, Taishō 1-5) (Taipei: Taiwan Sōtokufu zaimukyoku, zeimuka, 1918), p. 361.

[18] Man-houng Lin, "Qiaoxiang Ties versus Japanese Maritime Power: Trade between Taiwan and Manchuria, ca. 1932-1939," in Leo Suryadinata ed., Chinese Diaspora, Since Admiral Zheng He, with Special Reference to Maritime Asia (Singapore: Chinese Heritage Center, May 2007).

[19] Taiwan's foreign exports and imports between 1906 and 1939 derived from Zhou Xianwen, Riju shiqi Taiwan zhi duiwai maoyi (Taiwan's foreign trade in the period of Japanese rule), Taiwan yinhang jikan (Quarterly of the Bank of Taiwan), vol. 9, no. 1 (Taipei: Taiwan yinhang jingji yanjiushi, 1957), p. 39, p. 50 , adding the two for the total trade value. Value for trade with Japan, from the same source, pp. 39 and 50, subtracted to give a total for trade with countries other than Japan. For the total value of Taiwan's trade with northeast China see Lin Manhong, 'Taiwan yu dongbei jian de maoyi, 1932-1941' (Trade between
Taiwan and northeast China, 1932-1941), Jindaishi yanjiusuo jikan (Bulletin of the Institute of Modern History, Academia Sinica), no. 24 (Taipei: Zhonyanyuan jinshisuo, June 1995), table 1 .

[20] From figures in Shengjing shibao (Shenyang: Shengjing shibao yingyin zu, 1985-1988), in 141 volumes), December 5, Shōwa 8.

[21] From figures in Shengjing shibao, January 22, Shōwa 14.

[22] Zhou Xianwen, Taiwan jingji shi (Economic history of Taiwan) (Taipei: Kaiming shudian, 1980), p. 624.

[23] Figures calculated from Zhou Xianwen, Riju shidai Taiwan jingji shi (Economic history of Taiwan under Japanese rule) (Taipei: Taiwan yinhang jingji yanjiushi, 1958), pp. 137, 150, from Taiwan sheng zhujichu, Taiwan maoyi 53 nian biao (Taiwan trade statistics for the last 53 years).

[24] Taiwan keizai nenpō kankōkai (Taiwan's annual economic report publishing committee) (ed.), Taiwan keizai nenpō (Taiwan's annual economic report) (Tōkyō: Kokusi Nihon Kyōkai, 1941), p. 603.

[25] Ye Lizhong, 'Taiwan jingji zai Zhongguo' (The Taiwanese economy in China), Taiwan Yinhang jikan (Quarterly of the Bank of Taiwan), first issue, 1956, p. 131.

[26] Taiwan keizai nenpō kankōkai (ed.), Taiwan keizai nenpō, p. 605.

[27] Zi Gu, 'Taiwan Jingji yu Riben' (The Taiwanese economy and Japan), Taiwan Yinhang jikan (Quarterly of the Bank of Taiwan), first issue (Taipei: Taiwan yinhang jinrong yanjiu shi, 1947), pp. 137-150, 145.

[28] Dan An, 'Taiwan jingji yu nanyang' (The Taiwanese economy and Southeast Asia), Taiwan Yinhang jikan, No. 1 (Taipei: Taiwan yinhang jingji yanjiushi, 1947), p. 155.

[29] Gaimushō Tsūshōkyoku, A-moi-ko boeki solun (A glance at the trade of the Amoy port), Tsūshō isan (Tōkyō: Genshinsha, 1902), p. 347

[30] See also: Man-houng Lin, "Economic Ties Between Taiwan and Mainland China, 1860-1895: Strengthening or Weakening?" in Hao Yan-p'ing and Wei Hsiu-mei ed., Tradition and Metamorphosis in Modern China, Symposium in Commemoration of Prof. Liu Kwang-Ching's 75th birthday, pp. 1067-1089, Taipei: Institute of Modern History, Academia Sinica, 1998. Man-houng Lin and Chung-sheng Chu, comp., The Exhibition on the First Floor of the President Office: From Governor-General Office to Presidential Office: The Story of Governor-Generals. 2nd ed. Taipei: Academia Historica, 2010, p. 69.

[31] Taiwan nichinichi shinpō, April 1, Shōwa 6. Wu Wenxing, Riju shidai zai Tai Huaqiao yanjiu (Overseas Chinese on Taiwan under Japanese rule) (Taipei: Taiwan xuesheng shuju, 1991); see also discussion in Xu Xueji, 'Taiwan Zhonghua zonghuiguan chengliqian de Taiwan Huaqiao, 1895-1927' (Overseas Chinese on Taiwan before the establishment of the Chinese General Association, 1895-1927), Jindaishi yanjiusuo jikan (Bulletin for the research of modern history), no. 20, the Institute of Modern History, Academia Sinica, pp. 99-129.

[32] Taiwan Sotokufu, Taiwan jōjū kokō tōkei: Shōwa 18 (Taipei: Taiwan Sotokufu, 1944), pp. 2, 108 
[33] Taiwan Sōtokufu Chōsaka, Taiwan Sōtokufu dai san jū kyū tōkei sho (Shōwa 10) (Taiwan Governor-General's Office statistics no. 39, Shōwa 10) (Taipei: Taiwan Sotokufu, 1935), p. $86-87$

[34] Taiwan Sotokufu, Taiwan Sōtokufu dai yon jū roku tōkei sho (Shōwa 17) (Taiwan Governor-General's Office statistics no. 46, 1944) (Taipei: Taiwan Sotokufu, 1944), p. 60-67. See also discussion in Jin Jungwon, 'Zai zhimindi Taiwan shehui jiafengzhong de Chaoxian ren changjiye' (Standing in the Gap of Society: Korean Prostitutes in Colonial Taiwan), Taiwan shi yanjiu (Taiwan research bulletin), Zhongyang yanjiuyuan Taiwan shi yanjiusuo, vol. 17 no. 3 (September 2010), pp. 107-49.

[35] Taiwan nichinichi shinpō, June 2, Shōwa 9.

[36] After 1934, the Taiwan nichinichi shinpō mentions only the establishment of a Manchurian Consulate in Ōsaka on March 3, Shōwa 16.

[37] Taiwan Sōtokufu Sōtoku Kanbō Gaijika, Taiwan to minami Shina (Taiwan and south China), Minami Shina oyobi Nan'yō chōsa, no. 236, Taipei, 1937, p. 13.

[38] Lin Zhen, 'Kangzhan shiqi Fujian de Taiwan ji min wenti' (On Taiwanese people in Fujian during the Anti-Japanese War), Taiwan yanjiu jikan (Taiwan research bulletin), no. 2 of 44 , Xiamen: Taiwan yanjiusuo, 1994, p. 71.

[39] Ogi Shusei, "Zaiko taiwan jin no kinkyō," Taiwan jihō (Taiwan Times), Taipei: Taiwan jihō hakkōsho, May, 1938, p. 160.

[40] Shengjing shibao, 9th August Shōwa 13.

[41] Xu Xueji ed., Koushu lishi (Oral history), no. 5, Taipei: Zhongyang yanjiuyuan jindaishi yanjiusuo, 1994, p. 318.

[42] Suekichi Ihara, Seikatsujō yori mitaru Taiwan no jissai (Taiwan's reality with the perspective of the livelihood), Taipei, 1925 , p. $77-78$

[43] Yang Jiancheng, Erci dazhan Riben qitu liyong Riji Huaqiao shentou Nanyang qiaoshe miwen (The hidden story of Japan's efforts to use overseas Chinese with Japanese citizenship to infiltrate the overseas Chinese in Southeast Asia), Hongguan bao (Broad views times), January 28, 1994. Many thanks to $\mathrm{Mr}$ Yang for providing me with this article.

[44] Guo Fang, Zainichi Kakyō no aidentiti no hen'yō: Kakyō no tagenteki kyōsei (The changing identity of Chinese in Japan: their multidimensional acculturation) (Tōkyō: Tōshindō, 1999), p. 45, quoting Japanese government statistics.

[45] Lin Zhen, 'Kangzhan shiqi Fujian de Taiwan jimin wenti', p. 72.

[46] Man-houng Lin, 2019, "Culture, Market, and State Power: Taiwanese Investment in Southeast Asia, 1895-1945", editor(s): Chi-cheung Choi, Takashi Oishi, Tomoko Shiroyama, Chinese and Indian Merchants in Modern Asia Networking Businesses and Formation of Regional Economy, pp. 258-281, Leiden: Brill..

[47] See e.g. Prasenjit Duara, Sovereignty and Authenticity: Manchukuo and the East Asian Modern (Lanham, Boulder, New York, Oxford: Rowman \& Littlefield Publishers, Inc., 2003).

[48] Ozaki Hozuma at al, tr. Yang Yongliang, Gu Xianyong zhuan (Biography of Gu Xianyong) (Taipei: Taiwan ririxin bao, 1939; translated and reprinted Taipei Wu Sanlian jijinhui, 2007), pp. 235-277.

[49] Wang Yeh-chien, Qingdai jingjishi lunwenji: san (Collected essays on the economic history of Qing China, part three), Taipei: Daoxiang chubanshe, 2003, p. 195.

[50] Taiwan sheng wenxian weiyuanhui, Taiwan sheng tongzhi (Taiwan province gazetteer), vol. 4, Economy, Commerce, Taipei: Taiwan sheng wenxian weiyuanhui, 1971, p. $283 \mathrm{~b}$.

[51] Zheng Liling, Yang Lizhu, Taibei gongyesheng de huiyi (Recollections of Taipei engineering students, Taipei: National Taipei University of Technology, 2009, pp. 52, 123.

[52] Man-houng Lin, "Overseas Chinese Merchants and Multiple Nationality of: A Means for Reducing Commercial Risk," Modern Asian Studies 35:4:985-1010, Cambridge University.

[53] Man-houng Lin, "The Power of Culture and Its Limits: Taiwanese Merchants' Asian Commodity Flow, 1895-1945," in Eric Tagliacozzo and Wen-Chin Chang eds., Chinese Circulations: Capital, Commodities and Networks in Southeast Asia, Durham, N. C.: Duke University Press, 2011, pp. 305-335.

[54] Taiwan Xinminbao she (eds.), Taiwan renming cidian (Dictionary of Taiwanese names), Taipei: Taiwan xinminbao she, 1937; reprinted Nihon Tosho Sentā, 1989, p. 82.

[55] Man-houng Lin, "Taiwan, Manchukuo, and the Sino-Japanese War," Asian Social Science (Canadian Center of Science and Education," vol. 7, no. 6, June 2011. This study shows that around four hundred people went to China to join the Revolutionary Alliance (Geming Tongmenghui), while many of the remaining twenty-to-thirty thousand Taiwanese citizens in China worked with the Japanese; I also argue that during the war, the destiny of the around five-to-six million Taiwanese were closely linked to those of Japan. See also: Man-houng Lin, "The Greater East Asia Co-prosperity Sphere': A New Boundary for Taiwanese People and the Taiwanese Capital, 1940-1945," Translocal Chinese: East Asian Perspective (Leiden: Brill Co.), no. 11 (Oct., 2016), pp. 175-206.

[56] Man-houng Lin, "The Survival of Economic Elites during Regime Transition: Government-Merchant Cooperation in Taiwan's Trade with Japan, 1950-1961", in Shigeru Akita and Nicholas J. White eds., International Order of Asia in the 1930s and 1950s: Contexts, Hypotheses and Scope, London and New York: Ashgate, 2010, pp. 275-301.

[57] Anne Booth and Kent Deng, 'Japanese Colonialism in Comparative Perspective,' The Journal of World History, 28/1 (2017), pp. 61-98. 